\title{
Adipose stem cells may promote cancer progression
}

\begin{tabular}{|c|c|c|}
\hline $\begin{array}{l}\text { or } \\
\text { dicine } \\
\text { eliable' } \\
\text { e easily } \\
\text { ed from } \\
\text { research } \\
\text { a of } \\
\text { Centre } \\
\text { my } \\
\text { Genetics }\end{array}$ & $\begin{array}{l}\text { tem cell-based therapies have } \\
\text { carried the hopes of researchers, } \\
\text { physicians and patients for over } \\
\text { thirty years, showing great promise in their } \\
\text { ability to restore damaged and diseased } \\
\text { organs and tissue. Most stem cell } \\
\text { therapies rely on adult stem cells called } \\
\text { mesenchymal stem cells (MSCs), which } \\
\text { can differentiate into cartilage, bone, } \\
\text { connective tissue, muscle or adipose (fat) } \\
\text { tissue. MSCs can be obtained from almost } \\
\text { any organs or tissues (bone marrow, lung, } \\
\text { spleen, liver, fat etc.). The MSCs derived } \\
\text { from fat tissue are called adipose stem } \\
\text { cellls (ASCs) and these can be isolated } \\
\text { with minimal ethical conflict. } \\
\text { Until recently, bone marrow served as } \\
\text { the main source of MSCs. However, } \\
\text { adipose tissue became much more } \\
\text { attractive as researchers realised that } \\
\text { AsCs were abundantly available and } \\
\text { could be easily and repeatedly sampled } \\
\text { with minimally invasive procedures. } \\
\text { Furthermore, adipose stem cells have } \\
\text { demonstrated low immunogenicity (i.e., } \\
\text { they are unlikely to react with the immune } \\
\text { system) and some immunosuppressive } \\
\text { properties which prevent the body from } \\
\text { rejecting them - making them safe for } \\
\text { therapeutic use. As a result, ASCs have } \\
\text { been used in several } \\
\text { clinical trials to treat } \\
\text { conditions such } \\
\text { as diabetes } \\
\text { mellitus, liver } \\
\text { disease, } \\
\text { traumatic } \\
\text { injuries and } \\
\text { corneal }\end{array}$ & $\begin{array}{l}\text { Now, research led by Dr Robert Katona } \\
\text { of the Biological Research Centre of } \\
\text { the Hungarian Academy of Sciences' } \\
\text { Institute of Genetics has shown that } \\
\text { ASCs with an abnormal number of } \\
\text { chromosomes may promote cancer } \\
\text { development and act as tumour support } \\
\text { structures, known as stroma. } \\
\text { INVESTIGATING ASC } \\
\text { BEHAVIOUR IN MICE } \\
\text { In order to get a better understanding } \\
\text { of ASC behaviour, Dr Katona and his } \\
\text { team extracted the visceral fat - the deep } \\
\text { abdominal fat that surrounds organs } \\
\text { - from mice and cultured the visceral } \\
\text { adipose stem cells (vASCS) in vitro } \\
\text { for several months. } \\
\text { The changes were almost immediate } \\
\text { and cell growth and division slowed } \\
\text { down, with cell numbers decreasing in } \\
\text { the first few weeks. Soon after, the cells } \\
\text { began to deteriorate, becoming enlarged } \\
\text { and flattened, with most stopping } \\
\text { growth and proliferation altogether. } \\
\text { Surprisingly, however, some continued to } \\
\text { divide and after } 50 \text { days, the cell culture } \\
\text { had grown beyond the initial sample size. } \\
\text { By now, the cells were showing signs } \\
\text { of increased DNA content, with most } \\
\text { cells having four or more copies of } \\
\text { at least one chromosome, rather than }\end{array}$ \\
\hline
\end{tabular}
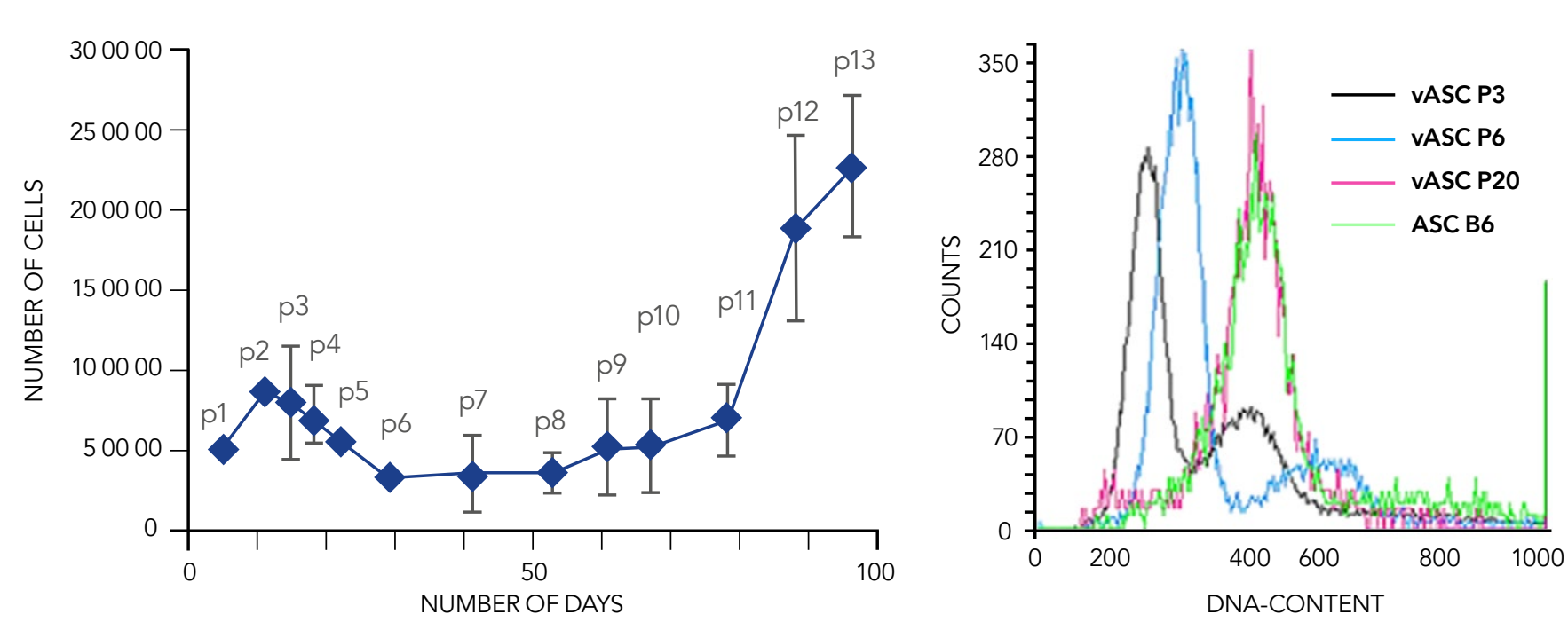

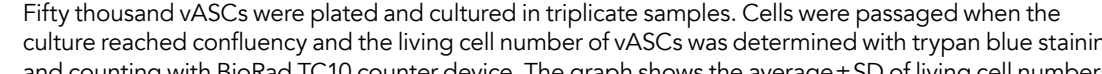
and counting with BioRad TC10 counter device. The graph shows the average \pm SD of living cell numbers
in three parallel samples. The $x$-axis indicates days in culture from the initial plating, and the measuring

points are referred as p1 to p13. A representative

the usual two, causing cells to have even up to 163 chromosomes in total, rather using flow cytometry - where a liquid cell culture is poured down a tube and passed through one or more lasers to determine the physical and chemica properties of the cells - and microscopy. In both cases, DNA within the cells was stained so that it would fluoresce whe hit with a laser and become visible to the researchers.

This result is significant as multiple DNA copies can lead to altered gene

To see how the cells' gene expression and behaviour had changed, the ASC cell line, containing the abnormal DNA configuration which they called ASC.B6 and compared its activity to original vASCs. While the ASC B6 cells were still able to differentiate into mature cells as normal, transcriptome analysis - study of the total sum of messenger RNA (an intermediary between DNA and proteins) present in the cell - showed that 2395 genes were being expressed at least twice as much or as low as norma.

In particular, genes and gene products responsible for cell growth, division in ASC.B6, showing that these cells might be involved in cancer development. This was backed by

increased expression of cancer stem cell like growth factor 1 (IGF1), increased markers Sca-1, CD29, and Krüppel-like in ASC.B6 compared to vASCs (IGF1
factor 4 (Klf4). Interestingly, expression

New research lead by Dr Robert Katona has shown that ASCs ... may promote cancer development and act as tumour support structures. of another cancer stem cell marker,

ASCS CAN PROMOTE TUMOUR CELL GROWTH

To demonstrate this, Dr Katona and his team co-cultured the 4 TY murine breast Both ASC cultures enhanced proliferation of 4T1, although ASC B6 did so for more than the vASCs Surprisingly most of the tumour-promoting growth factors were expressed at similar levels in both vASC and ASC.B6. However, expression of one tumour-promoting growth factor, insulin-
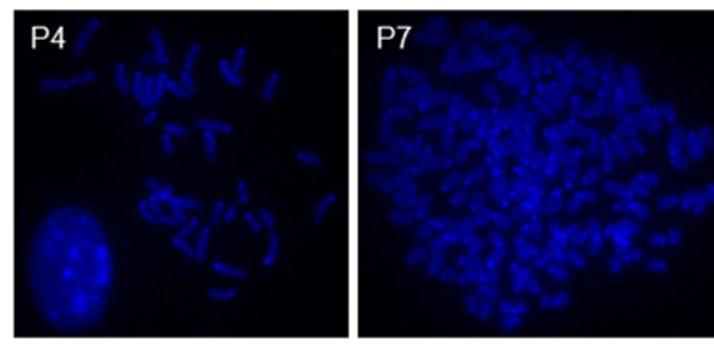

Metaphase chromosome spreads were made from colchicine-blocked when they started to show increased DNA content) and was found in the bro surrounding both cultures. Moreover, treatment with an IGF1 antibody significantly decreased tumour growth, tumour growth promoting effect.

\section{WHY IGF1?}

GF1 is responsible for promoting mammary terminal end bud, ductal and gland formation in healthy mammals. is also expressed in mammary stromal

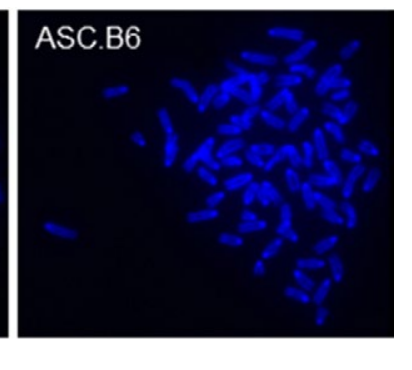
t least partly responsible for ASC B6S 

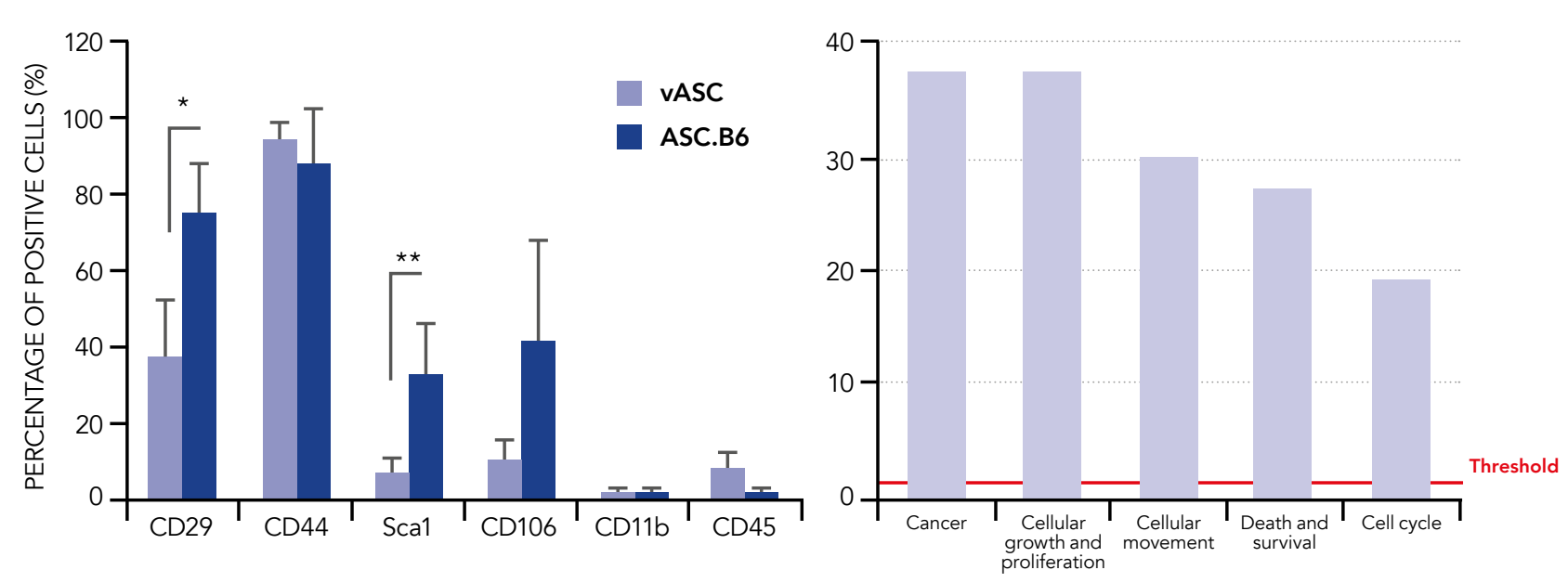

Cell surface markers of VASCS at passage 3 and ASC.BB cells were
detected by flow cytometry and the percentage of positive cells was experiments, the statistical analysis was $\mathrm{t}$-test with $\mathrm{P}$-values set at:

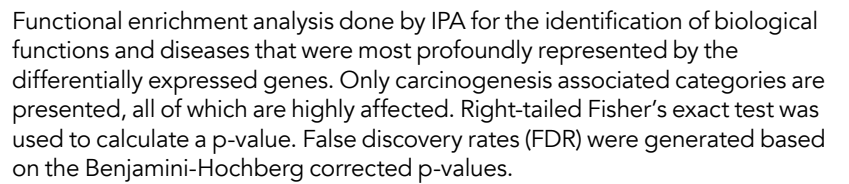

cells. As a result, overexpression of IGF can lead to breast cancer development progression and metastasis. This is pexposed murine breast cancer cells.

The tumour-promoting effect of IGF1 is often heightened when it binds to its receptor - IGF1R. This makes it a promising target for human breast cancer therapies and several researchers have Iready attempted clinical trials that treat breast cancer with IGFIR or receptor tyrosine kinase inhibitors. Unfortunately, these clinical trials were stopped as IGF1 antibody therapy caused hyperglycaemia

By now, the cells were showing signs of increased DNA content, with... cells having up to 163 chromosomes in total, rather than the usual 40.

- increased blood sugar - and metabolic like a lot of effort, finding effective syndrome in patients while receptor tyrosine kinase inhibitors led to patients developing metabolic toxicities.

Currently, researchers are exploring alternative anti-IGFI antibodies, with some successfully slowing or even inhibiting cancer proliferation in late-

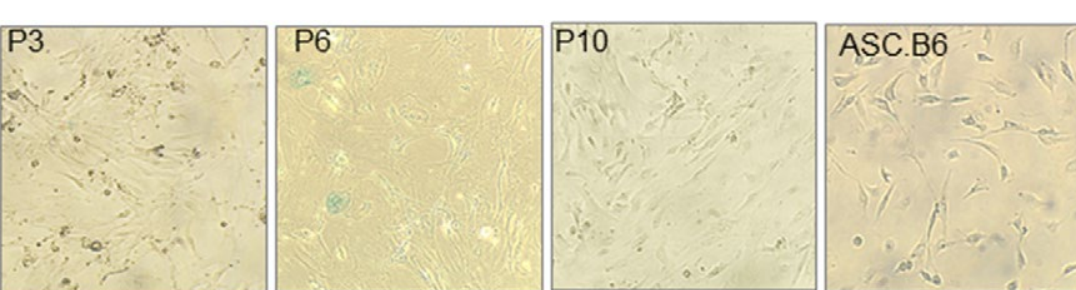

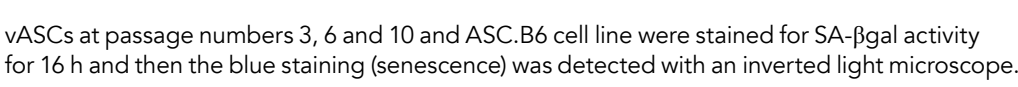

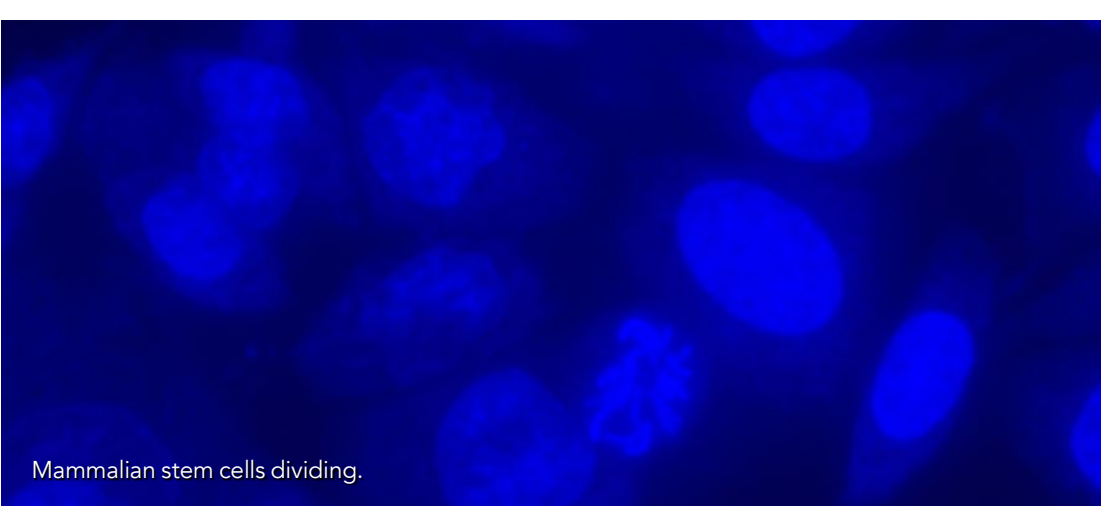
stroma, such as ASCs, is critical, as their secretion of IGF1 can lead to cancer drug resistance, minimising the effectiveness

\section{CAN THE MOUSE MODEL}

BE APPLIED TO PEOPLE?

Destona modes Dre used due to their high similarity with humans, (We share $85 \%$ of our proteinactivities observed in mice would most likely reflect those in humans. Just as in mice ASCs, ageing and deteriorating human ASC cultures have had altered chromosome numbers. Dr Katona expects this would also be the case in the body and could be due to higher concentrations of reactive oxygen pecies or inflammatory mediators which promote chronic inflammation in the tumour microenvironment.

While Dr Katona hopes that his mouse ASC model could be used for further research into the genes responsible for cancer development and potentia his findings could a ts influ stroma, his findings could also ind

\section{Behind the Research}

\section{Dr Robert Katona}

E: katona.robert@brc.mta.hu T: +3662433397 W: www.brc.hu/gen_acstem.php

\section{Research Objectives}

Dr Katona's work uses a mouse adipose stem cell model

\section{Detail}

Institute of Genetics

Biological Research Centre

garian Academy of Science

6726. Szeged, Temesvari krt. 62

Hungary

Bio

Dr Katona is Principal Investigator at the Artificial

Chromosome and Stem Cell Research Laboratory. He has 28 years' experience in basic research and R\&D research. His fields of expertise are molecular biology, biochemistry, cytology and industrial protein production.

Funding

This work was funded by the GINOP-2.3.2-15-2016-0000 and GINOP-2.3.2-15-2016-00039 grant of the Nationa

Research, Development and Innovation Office.

Collaborators

- Roberta Fajka-Boja

- Anna Toth

Peter Blazso

- Vilmos Tubak

- Balazs Balint

- Istvan Nagy

- Zoltan Hegedus

- Csaba Vizler

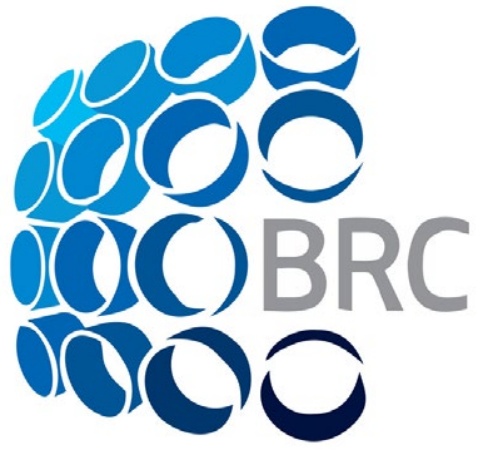

\section{References}

Fajka-Boja, R., Marton, A., Tóth, A., Blazso, P., et al. (2018). Increased insulin-like growth factor 1 production by polyploid adipose stem cells promotes growth of breast cancer cells. BMC Cancer, lonlinel, 18, 872-884. Avallable
at: https://bmccancer.biomedcentral.com/articles/10.1186/ at: https:///bmccancer.biomedcentral.com/atict.

Frese, L., Dijkman, P. and Hoerstrup, S. (2016). Adipose

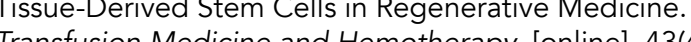
268-274. Available at: https://www.ncbi.nlm.nih.gov/pme/ articles/PMC5040903/[ [Accessed 22/01/2019].

Karanes, C. Nelson, G., Chitphakdithai, P. Agura, E, et al. (2008). Twenty Years of Unrelated Donor Hematopoietic Cell Transplantation for Adult Recipients Facilitated by the Marrow Transp Donor Program. Biology of Blood and https://wmmbbmtorg/article/S1083-8791(08)00249-8/ fulltext [Accessed 22/01/2019].

Miana, V. and González, E. (2018). Adipose tissue stem

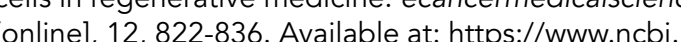
nlm.nih.gov/pmc/articles/PMC5880231/ [Accessed 22/01/2019].

Robertson, S. (2018). What is flow cytometry? [online]

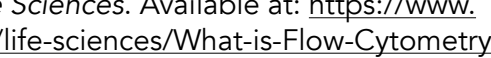
aspx [Accessed 22/01/2019].

(2010). Why mouse matters. Ionlinel National Human

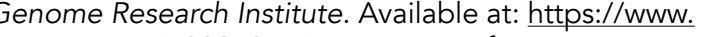
genome.gov/10001345/importance-of-mouse-genome/

\section{Personal Response}

Given your results, would you suggest people

II Yes, but people should receive ASC therapy only blind, regulated and controlled clinical trials. Any clinically unproven procedures should be strongly avoided. 